\title{
PENGARUH DEBT DEFAULT, FINANCIAL DISTRESS, OPINION SHOPPING DAN AUDIT TENURE TERHADAP PENERIMAAN OPINI AUDIT GOING CONCERN
}

\author{
Dea Izazi \\ Rizka Indri Arfianti* \\ Program Studi Akuntansi, Institut Bisnis dan Informatika Kwik Kian Gie \\ Jl. Yos Sudarso Kav. 87, Sunter Jakarta 14350
}

\begin{abstract}
Going concern is always linked with management capabilities in managing the company in order for the company to survive. The audit report with the modification of going concern is an indication that in the auditor's judgment there is a risk that the entity can not survive in the business world. Provision of going concern audit opinion by the auditors often addressed as bad news by the company, because it is alleged to cause the company to become bankrupt quickly. This study aims to examine the effect of debt default, financial distress, opinion shopping and audit tenure to the acceptance of going concern audit opinion. The sampling technique used in this study is purposive sampling with a total sample of 180 non-financial companies listed on the Indonesia Stock Exchange during the period of research year 2014-2016. Hypothesis testing of this research is done by logistic regression analysis using SPSS ver20. The result of this study shows that debt default and financial distress have significant value of 0,000 and 0,019, respectively. While audit tenure and opinion shopping have significant value of 0.000 and 0.0105 , respectively. The conclusion of this study showed that debt default and financial distress are significantly affect on the acceptance of going concern audit opinion, while the opinion shopping and audit tenure are not significantly affect on the acceptance of going concern audit opinion.
\end{abstract}

Keywords: Going Concern Audit Opinion, Debt Default, Financial Distress, Opinion Shopping, Audit Tenure

\begin{abstract}
ABSTRAK
Going concern selalu dihubungkan dengan kemampuan manajemen dalam mengelola perusahaan agar perusahaan dapat bertahan hidup. Laporan audit dengan modifikasi mengenai going concern merupakan suatu indikasi bahwa dalam penilaian auditor, terdapat risiko bahwa entitas tidak dapat bertahan dalam dunia bisnis. Pemberian opini audit going concern oleh auditor seringkali disikapi sebagai bad news oleh perusahaan, karena disinyalir dapat menyebabkan perusahaan menjadi cepat bangkrut. Penelitian ini bertujuan untuk meneliti pengaruh debt default, financial distress, opinion shopping dan audit tenure terhadap penerimaan opini audit going concern. Teknik pengambilan sampel yang digunakan adalah purposive sampling dengan jumlah sampel sebanyak 180 perusahaan non keuangan yang terdaftar di Bursa Efek Indonesia selama periode penelitian tahun 2014-2016. Pengujian hipotesis penelitian ini dilakukan dengan analisis regresi logistik dengan SPSS ver20. Hasil pengujian hipotesis menunjukkan debt default dan financial distress memiliki nilai signifikansi berturut-turut 0,000 dan 0,019. Sedangkan hasil pengujian hipotesis opinion shopping dan audit tenure memiliki nilai signifikansi berturut-turut 0,000 dan 0,0105. Kesimpulan dari hasil penelitian ini adalah debt default dan financial distress cukup bukti berpengaruh signifikan positif terhadap penerimaan opini audit going concern, sedangkan opinion shopping dan audit tenure tidak cukup bukti berpengaruh terhadap penerimaan opini audit going concern.
\end{abstract}

Kata Kunci: Opini Audit Going Concern, Status Utang, Kesulitan Keuangan, Belanja Opini, Ikatan Audit

*Alamat kini: Institut Bisnis dan Informatika Kwik Kian Gie, Jl. Yos Sudarso Kav. 87, Sunter Jakarta 14350

Penulis untuk Korespondensi: Telp. (021) 65307062 Ext. 708. Email: rizka.indri@kwikkiangie.ac.id 


\section{Pendahuluan}

Dunia bisnis yang dinamis menuntut para pelaku didalamnya untuk selalu berhati - hati agar kelangsungan usahanya dapat terjaga dan terhindar dari kepailitan. Kasus pailit telah sering terjadi baik di Indonesia maupun dunia. Sebut saja Enron dan Lehman Brothers, kepailitan keduanya membawa dampak yang begitu besar bagi perekonomian negara-negara sekitar tak terkecuali Indonesia. Di Indonesia sendiri kasus kepailitan telah menimpa sejumlah perusahaan, 2 diantaranya yaitu PT Nyonya Meneer selaku perusahaan pribadi dan PT Dwi Aneka Jaya Kemasindo atau lebih dikenal dengan kode emiten DAJK yang telah go public. Kedua perusahaan dinyatakan pailit oleh Pengadilan Negeri setempat setelah digugat oleh kreditor karena memiliki beban utang yang berat kepada sejumlah kreditor. Beratnya beban utang membuat perusahaan tak lagi sehat dan tidak dapat melunasi utangnya seperti yang telah disepakati diawal perjanjian utang. Peristiwa kepailitan tersebut mengindikasikan bahwa tidak semua perusahaan yang belum ataupun sudah tercatat di Bursa Efek Indonesia memiliki kelangsungan usaha (going concern) yang prospektif dimasa depan.

Going concern suatu perusahaan selalu dihubungkan dengan kemampuan manajemen dalam mengelola perusahaan agar dapat bertahan pada dunia bisnis yang dinamis. Opini audit going concern sendiri merupakan opini audit modifikasi yang dikeluarkan oleh auditor untuk memastikan apakah perusahaan dapat mempertahankan kelangsungan hidupnya setidaknya dalam satu tahun ke depan (SPAP seksi 341, 2011). Namun, pengeluaran opini ini seringkali disikapi sebagai bad news oleh perusahaan karena diyakini dapat menyebabkan perusahaan menjadi cepat bangkrut sebab pengguna laporan keuangan merespon informasi tersebut secara negatif seperti investor membatalkan investasinya dan kreditor menarik pinjamannya. Meskipun demikian, opini audit going concern harus diungkapkan dengan harapan dapat segera mempercepat usaha penyelamatan perusahaan yang bermasalah.

Dalam pernyataan Standar Auditing No.30 (SPAP seksi 341, 2011), indikator going concern yang banyak dipakai oleh auditor dalam memberikan keputusan terkait opini auditnya adalah kegagalan dalam memenuhi kewajiban utang (default). Debt default merupakan kegagalan debitur (perusahaan) untuk melunasi utang pokok maupun bunganya kepada kreditur pada waktu jatuh tempo (Chen dan Church, 1992 dalam Ramadhany, 2004). Menurut (Januarti, 2009), status utang perusahaan dapat dikatakan sebagai faktor utama yang akan diperiksa oleh auditor untuk mengukur kesehatan keuangan perusahaan. Jadi jika perusahaan sedang dalam kondisi default maka kemungkinan perusahaan tersebut mengalami kebangkrutan.

(Platt dan Platt, 2006) mendefinisikan financial distress sebagai tahap penurunan kondisi keuangan yang terjadi sebelum terjadinya kebangkrutan ataupun likuidasi. Menurut (McKeown et al., 1991) kondisi perusahaan yang buruk atau mengalami kesulitan keuangan akan meningkatkan kemungkinan perusahaan menerima opini audit going concern. Sebaliknya pada perusahaan yang tidak pernah mengalami kesulitan keuangan maka akan menurunkan kemungkinan perusahaan menerima opini audit going concern atau dengan kata lain, auditor tidak akan mengeluarkan opini audit going concern.

Opinion shopping didefinisikan oleh Security Exchange Commisiion (SEC) dalam (Harvey dan Espahbodi, 1991) sebagai kegiatan mencari auditor yang mau mendukung cara perlakuan akuntansi yang dilakukan oleh pihak manajerial untuk mencapai tujuan yang diinginkan perusahaan. Perusahaan biasanya mengganti auditor untuk menghindari penerimaan opini going concern. Tujuan melakukan opinion shopping adalah untuk meningkatkan atau memanipulasi hasil operasi atau kondisi keuangan perusahaan, sehingga perusahaan diharapkan mendapatkan opini audit wajar tanpa pengecualian dari auditor (Praptitorini dan Januarti, 2007). (Lennox, 2000) dalam penelitiannya berpendapat bahwa ketika perusahaan mengganti auditornya, maka akan menurunkan kemungkinan mendapatkan opini audit yang tidak diinginkan, daripada perusahaan yang tidak melakukan pergantian auditor. Perusahaan yang berhasil dalam opinion shopping melakukan pergantian auditor dengan harapan mendapat unqualified opinion dari auditor baru.

Independensi merupakan salah satu etika yang wajib dijunjung tinggi oleh auditor dalam melaksanakan pekerjaannya. Apabila auditor mengabaikan independensinya, maka auditor tersebut akan cenderung menjadi tidak objektif dan akan memihak kepada kliennya. Salah satu hal yang menyebabkan auditor menjadi tidak independen adalah hubungan perikatan yang sudah terlalu lama terjalin dengan klien (tenure). Auditor client tenure didefinisikan oleh (Januarti, 2009) sebagai jumlah tahun dimana auditor (KAP) melakukan perikatan audit dengan auditee yang sama. Lamanya perikatan antara auditor (KAP) dengan auditee dapat membuat auditor kehilangan 
independensinya, sehingga kemungkinan pengeluaran opini audit going concern akan semakin kecil atau justru akan membuat KAP lebih memahami kondisi keuangan dan akan lebih mudah mendeteksi masalah going concern (Januarti, 2009).

Penelitian ini bertujuan untuk mengetahui pengaruh debt default, financial distress, opinion shopping dan audit tenure terhadap penerimaan opini audit going concern. Penelitian ini diharapkan dapat bermanfaat bagi pihak praktisi agar dapat mengetahui tanda-tanda yang mengarah pada ketidakmampuan perusahaan dalam mempertahankan kelangsungan usahanya, sehingga pengambilan keputusan lebih akurat. Hasil penelitian ini juga diharapkan dapat bermanfaat sebagai sumber referensi bagi penelitian selanjutnya.

Beberapa kajian teori pendukung yang digunakan peneliti dalam penelitian ini antara lain:

\section{Teori Agensi}

Teori agensi didefinisikan oleh (Jensen dan Meckling, 1976) sebagai hubungan keagenan dalam suatu kontrak, dimana satu orang atau lebih (prinsipal) meminta orang lain (agen) untuk melakukan sejumlah pekerjaan atas nama prinsipal yang melibatkan pendelegasian beberapa wewenang kepada agen dalam hal pengambilan keputusan. Teori agensi menjelaskan tentang masalah keagenan yang timbul karena adanya konflik kepentingan antara prinsipal dan agen, sehingga mengakibatkan terjadinya asimetri informasi diantara kedua pihak tersebut. Dalam kaitannya dengan teori agensi, auditor independen berperan sebagai mediator akibat konflik kepentingan antara prinsipal dan agen dan berfungsi untuk mengurangi biaya agensi yang timbul atas konflik kepentingan tersebut.

\section{Opini Audit Going Concern}

Opini audit going concern merupakan opini yang dikeluarkan oleh auditor untuk memastikan apakah perusahaan dapat mempertahankan kelangsungan hidupnya setidaknya dalam satu tahun ke depan. Auditor harus mengevaluasi apakah terdapat kesangsian besar mengenai kemampuan entitas dalam mempertahankan kelangsungan hidupnya dalam jangka waktu pantas dengan memperhatikan beberapa kondisi yang dapat dijadikan dasar pertimbangan dalam pemberian opini audit going concern (SPAP seksi 341, 2011) yaitu: trend negatif, petunjuk lain tentang kemungkinan kesulitan keuangan, masalah internal dan masalah ekstrenal yang telah terjadi. Opini going concern diungkapkan setelah paragraf pendapat dalam laporan keuangan audit. Menurut (SPAP Seksi 341, 2011), opini audit yang termasuk opini audit going concern yaitu: wajar tanpa pengecualian dengan paragraf penjelas, wajar dengan pengecualian, tidak wajar dan tidak memberikan pendapat.

\section{Pengaruh Debt Default terhadap penerimaan Opini Audit Going Concern}

Debt default merupakan kegagalan debitur (perusahaan) untuk melunasi utang pokok maupun bunganya kepada kreditor pada waktu jatuh tempo (Chen dan Church, 1992 dalam Ramadhany, 2004). Dinyatakan dalam Pernyataan Standar Auditing No.30 (SPAP, IAI 2011 : 341), indikator going concern yang banyak dipakai oleh auditor dalam memberikan keputusan terkait opini auditnya adalah kegagalan dalam memenuhi kewajiban utang (default). Berdasarkan hal tersebut, adanya status debt default diharapkan dapat meningkatkan kemungkinan auditor mengeluarkan laporan yang berisikan opini mengenai going concern perusahaan. (Chen dan Church, 1992 dalam Ramadhany, 2004) menemukan adanya hubungan yang kuat antara status debt default dengan penerimaan opini audit going concern. Dengan kata lain, status debt default menjadi indikasi adanya masalah going concern pada perusahaan. Konsisten dengan hasil penelitian Chen dan Church (1992), beberapa penelitian yang telah dilakukan oleh (Ramadhany 2004; Praptitorini dan Januarti 2007; Januarti 2009; Astuti dan Darsono 2012; Nirmalasari 2014) mendapatkan bukti empiris bahwa debt default berpengaruh signifikan positif terhadap penerimaan opini going concen yang menunjukkan bahwa adanya status debt default, semakin besar kemungkinan perusahaan menerima opini audit going concern. Ha1: Debt default berpengaruh positif terhadap penerimaan opini audit going concern

\section{Pengaruh Financial Distress Terhadap Penerimaan Opini Audit Going Concern}

Kondisi keuangan perusahaan dapat menggambarkan tingkat kesehatan perusahaan. Perusahaan dengan kondisi keuangan yang menurun atau tidak sehat dapat menjadi pertanda bahwa perusahaan tersebut sedang mengalami financial distress. Kondisi financial distress merupakan hal yang tidak diharapkan oleh perusahaan karena dengan kondisi tersebut investor dapat menarik kembali atau membatalkan investasinya. Menurut (McKeown et al. 1991) kondisi perusahaan yang buruk atau mengalami kesulitan keuangan akan meningkatkan kemungkinan perusahaan menerima opini audit going concern. 
Sebaliknya pada perusahaan yang tidak pernah mengalami kesulitan keuangan maka akan menurunkan kemungkinan perusahaan menerima opini audit going concern atau dengan kata lain, auditor tidak akan mengeluarkan opini audit going concern. Penelitian yang dilakukan oleh (Ramadhany 2004; Fanny dan Saputra 2005; Santosa dan Wedari 2007; Aziz 2008; Susanto 2009) telah menemukan bukti bahwa kondisi keuangan perusahaan berpengaruh signifikan terhadap penerimaan opini audit going concern. Hasil penelitian mereka membuktikan bahwa perusahaan dengan kondisi keuangan yang buruk (financial distress) membuat auditor cenderung memberikan opini audit going concern.

Ha2: Financial distress berpengaruh positif terhadap penerimaan opini audit going concern

\section{Pengaruh Opinion Shopping Terhadap Penerimaan Opini Audit Going Concern}

Opinion Shopping biasanya dilakukan oleh perusahaan dengan cara mengganti auditor untuk menghindari penerimaan opini going concern. (Lennox, 2000) dalam penelitiannya berpendapat bahwa ketika perusahaan mengganti auditornya, maka akan menurunkan kemungkinan mendapatkan opini audit yang tidak diinginkan, daripada perusahaan yang tidak melakukan pergantian auditor. Penelitian yang dilakukan oleh (Lennox, 2000) pada perusahaan di Inggris mendapatkan bukti bahwa opinion shopping berpengaruh negatif signifikan terhadap opini audit going concern.

Ha3: Opinion Shopping berpengaruh negatif terhadap penerimaan opini audit going concern

\section{Pengaruh Audit Tenure Terhadap Penerimaan Opini Audit Going Concern}

Lamanya perikatan antara auditor (KAP) dengan auditee dapat membuat auditor kehilangan independensinya, sehingga kemungkinan pengeluaran opini audit going concern akan semakin kecil atau justru akan membuat auditor lebih memahami kondisi keuangan dan akan lebih mudah mendeteksi masalah going concern (Januarti, 2009). Dalam penelitian yang dilakukan oleh (Januarti, 2009; Junaidi dan Hartono 2010; Krissindiastuti dan Rasmini 2016) didapatkan bukti empiris yang menyatakan bahwa audit tenure berpengaruh negatif terhadap penerimaan opini audit going concern. Menurut (Junaidi dan Hartono, 2010) pengaruh negatif tersebut menandakan bahwa semakin lama hubungan auditor dengan klien, maka semakin kecil kemungkinan perusahaan untuk mendapatkan opini audit going concern.
Ha4: Audit tenure berpengaruh negatif terhadap penerimaan opini audit going concern.

\section{Metode Penelitian}

Objek dalam penelitian ini adalah seluruh perusahaan yang sudah go public dan terdaftar di Bursa Efek Indonesia (kecuali perusahaan yang bergerak dalam sektor keuangan) pada tahun 2014-2016. Seluruh perusahaan ini harus memiliki laporan keuangan tahun 2014-2016 untuk tahun buku yang berakhir 31 Desember. Laporan keuangan yang dimaksud merupakan laporan keuangan yang telah diaudit dan memiliki opini audit atas laporan keuangan dalam satu periode akuntansi.

\section{Variabel Penelitian}

\section{Opini Audit Going Concern}

Opini audit going concern adalah opini audit dengan paragraf modifikasi yang diberikan oleh auditor jika terdapat keraguan mengenai kemampuan perusahaan dalam mempertahankan kelangsungan hidupnya. Menurut (SPAP Seksi 341, 2011), opini audit yang termasuk opini audit going concern yaitu: wajar tanpa pengecualian dengan paragraf penjelas, wajar dengan pengecualian, tidak wajar dan tidak memberikan pendapat. Variabel ini diukur dengan menggunakan variabel dummy. Perusahaan yang mendapatkan opini audit going concern diberi kode "1", sedangkan perusahaan yang mendapatkan opini audit non going concern (opini wajar tanpa pengecualian) diberi kode " 0 ".

\section{Debt Default}

Variabel debt default diukur dengan menggunakan variabel dummy untuk menunjukkan apakah perusahaan dalam keadaan default atau tidak sebelum pengeluaran opini audit. Penentuan variabel dummy mengacu pada penelitian yang dilakukan oleh (Astuti dan Darsono, 2012) dimana kode "1" diberikan jika perusahaan memiliki ekuitas negatif, dan kode " 0 " jika perusahaan memiliki ekuitas positif.

\section{Financial Distress}

Financial distress diukur dengan menggunakan model prediksi kebangkrutan Revised Altman, yang terkenal dengan nama Z' score. Model prediksi tersebut merupakan suatu formula yang dikembangkan oleh Altman untuk mendeteksi kebangkrutan perusahaan pada beberapa periode sebelum terjadinya kebangkrutan. Modifikasi model atau revisi yang dilakukan pada prediksi kebangkrutan dimaksudkan untuk membuat alat prediksi ini lebih 
relevan dengan masa lalu maupun kondisi yang akan datang (Altman, 2000). Formulanya adalah sebagai berikut :

$Z^{\prime}=0.717 \mathrm{Z1}+0.847 \mathrm{Z} 2+3.107 \mathrm{Z} 3+0.420 \mathrm{Z} 4+0.998$ Z5

Keterangan :

$\mathrm{Z} 1$ = working capital $/$ total assets

$\mathrm{Z} 2$ = retained earnings $/$ totals assets

$\mathrm{Z3}=$ earnings before interest and taxes / total assets

$\mathrm{Z} 4$ = book value of equity / book value of debt

$\mathrm{Z5}=$ sales $/$ total assets

Berdasarkan analisis tersebut, (Altman, 2000) mengklasifikasikan nilai Z menjadi 3 kategori. Apabila nilai $Z$ dari perusahaan yang diteliti lebih kecil dari 1,21 $\left(Z^{\prime}<1,21\right)$, maka perusahaan beresiko tinggi mengalami kebangkrutan (distress zone). Bila nilai $\mathrm{Z}$ berada diantara 1,23 sampai dengan 2,90 (1,23< Z' < 2,90), maka perusahaan dikatakan masih memiliki resiko kebangkrutan (gray area). Namun bila nilai Z di atas 2,90 (Z'> 2,90), maka perusahaan dinyatakan aman dari kebangkrutan (safe zone). Pada penelitian ini, hasil perhitungan $Z$ ' score kemudian akan dikelompokkan menggunakan variabel dummy, yaitu kode " 1 " untuk perusahaan yang benar-benar dalam kondisi kesulitan keuangan atau distress zone dengan nilai Z kurang dari 1,21 ( $\mathrm{Z}<1,21)$ dan kode " 0 " untuk perusahaan yang berada pada gray area dan safe zone dengan nilai $Z$ lebih dari $1,21(Z>1,21)$. Penggunaan dummy untuk penentuan perusahaan yang sedang mengalami kesulitan keuangan mengacu pada penelitian (Altman, 2000) yang mengelompokkan perusahaan menjadi 2 kategori yaitu bangkrut dan tidak bangkrut dan penelitian yang sudah pernah dilakukan sebelumnya oleh (Aziz, 2008).

\section{Opinion Shopping}

Pengukuran opinion shopping dalam penelitian ini mengacu pada metode yang diterapkan oleh (Lennox, 2000). Variabel ini diukur dengan dengan variabel dummy, dimana kode " 1 " diberikan kepada perusahaan diaudit oleh auditor independen yang berbeda untuk tahun selanjutnya setelah perusahaan mendapatkan opini audit going concern, sedangkan kode " 0 " diberikan kepada perusahaan diaudit oleh auditor independen yang sama untuk tahun selanjutnya setelah perusahaan mendapatkan opini audit going concern.

\section{Audit Tenure}

Variabel audit tenure menggunakan skala interval sesuai dengan lama hubungan KAP dengan perusahaan. (Krissindiastuti dam Rasmini, 2016) dalam penelitiannya mengukur auditor tenure dengan menghitung jumlah tahun dimana KAP yang sama telah melakukan perikatan audit terhadap auditee. Tahun pertama perikatan dimulai dengan angka 1 dan ditambah dengan satu untuk tahun-tahun berikutnya.

\section{Teknik Pengumpulan Data}

Penelitian ini menggunakan data sekunder, yaitu data yang diperoleh peneliti secara tidak langsung melalui perantara, seperti orang lain atau dokumen. Data sekunder dalam penelitian ini adalah data laporan auditor independen dan laporan keuangan tahunan perusahaan non keungan yang terdaftar di Bursa Efek Indonesia Periode 2014-2016. Data yang digunakan dalam penelitian ini diperoleh dari website Bursa Efek Indonesia (www.idx.co.id).

\section{Teknik Pengambilan Sampel}

Teknik pengambilan sampel yang digunakan dalam penelitian ini adalah non-probability sampling dengan pendekatan purposive sampling, dimana perusahaan-perusahaan yang menjadi sampel harus memenuhi kriteria tertentu yang telah ditentukan oleh penulis. Kriteria-kriteria yang digunakan dalam pengambilan sampel adalah sebagai berikut:

1. Perusahaan selain sektor keuangan yang terdaftar di Bursa Efek Indonesia dari Januari 2014 dan tidak keluar (delisting) selama periode penelitian, yaitu 2014-2016

2. Perusahaan yang mempublikasikan laporan keuangan secara lengkap serta menyajikan laporan auditor independen dalam periode 2014-2016.

3. Perusahaan yang memiliki laporan keuangan yang berakhir 31 Desember dan disajikan dalam mata uang Indonesia (Rupiah).

4. Perusahan mengalami laba bersih setelah pajak yang negatif minimal 2 tahun berturut-turut selama periode pengamatan 2014-2016.

\section{Teknik Analisis Data}

1. Analisis Statistik Deskriptif

Analisis statistik deskriptif digunakan untuk memberikan gambaran dan deskripsi mengenai variabel-variabel yang ada dalam penelitian. Analisis statistik deskriptif dilihat dari jumlah, sampel, nilai minimum, nilai maksimum, nilai rata-rata (mean), dan standar deviasi (Ghozali, 2016:19)

2. Uji Kesamaan Koefisien (Time Effect) 
Penelitian ini menggunakan data time series. Oleh karena itu, perlu dilakukan suatu pengujian untuk mengetahui apakah pooling data penelitian (penggabungan data cross-sectional dengan time series) dapat dilakukan. Pengujian ini dilakukan untuk mengetahui apakah ada perbedaan intercept, slope, atau keduanya di antara pesamaan regresi yang ada. Bila terbukti terdapat perbedaan intercept, slope atau keduanya diantara persamaan regresi, maka data penelitian tidak di-pool, melainkan harus diteliti secara cross-sectional. Sebaliknya, jika tidak terdapat perbedaan intercept, slope, atau keduanya diantara persamaan regresi, pooling data penelitian dapat dilakukan. Uji kesamaan koefisien dilakukan dengan menggunakan variabel dummy dalam penelitian ini mengambil periode 2014-2015. Bila signifikan dummy tersebut diatas nilai $\alpha=5 \%$ maka penelitian dapat di pool. Pengujian ini menggunakan bantuan program SPSS 20.00.

3. Regresi Logistik

Pengujian hipotesis dalam penelitian ini menggunakan analisis regresi logistik (logistic regression), dimana variabel independennya merupakan kombinasi antara variabel kontinyu (metric) dan kategorial (non metric). Regresi logistik adalah regresi yang digunakan untuk menguji apakah probabilitas terjadinya variabel dependen dapat diprediksi dengan variabel independen. Pada teknik analisa regresi logistik tidak memerlukan lagi uji normalitas pada variabel bebasnya (Ghozali, 2016:321). Berikut regresi logistik yang digunakan dalam penelitian ini:

$$
\begin{gathered}
\operatorname{Ln} \frac{O G C}{1-O G C}=\beta \mathrm{o}+\beta 1 \mathrm{DD}+\beta 2 \mathrm{FD}+\beta 3 \mathrm{AT}+\beta 4 \mathrm{OS} \\
+\varepsilon
\end{gathered}
$$

Keterangan:

$\begin{array}{ll}\operatorname{Ln} \frac{O G C}{1-O G C} & =\text { Opini Going Concern } \\ \text { DD } & =\text { Debt Default } \\ \text { FD } & =\text { Financial Distress } \\ \text { AT } & =\text { Audit Tenure } \\ \text { OS } & =\text { Opinion Shopping } \\ \beta o & =\text { Konstanta } \\ \beta 1-\beta 4 & =\text { Koefisien Regresi } \\ \mathcal{E} & =\text { Residual / Error }\end{array}$

a. Menilai Keseluruhan Model Fit (Overall Model Fit)

Penilaian model fit pada intinya untuk menilai overall fit model terhadap data. Likelihood $\mathrm{L}$ dari model adalah probabilitas bahwa model yang dihipotesakan menggambarkan data input. Penurunan Likelihood (-2LogL) menunjukkan model regresi yang lebih baik atau dengan kata lain model yang dihiposesiskan fit dengan data. Statistik 2LogL kadang disebut likelihood rasio $x^{2}$ statistik (Ghozali, 2016:328).

b. Koefisien Determinasi (Nagelkerke's $R$ Square)

Koefisien determinasi $\left(R^{2}\right)$ pada intinya mengukur seberapa jauh kemampuan model dalam menerangkan variasi variabel dependen. Nilai Nagelkerke's $R$ Square dapat diinterpretasikan seperti nilai $R^{2}$ pada multiple regression (Ghozali, 2016:329). Nilai $R^{2}$ yang kecil berarti kemampuan variabel-variabel independen dalam menjelaskan variasi variabel dependen amat terbatas. Sebaliknya, nilai yang mendekati satu berarti variabelvariabel independen memberikan hampir semua informasi yang dibutuhkan untuk memprediksi variasi variabel independen.

c. Menilai Kelayakan Model Regresi

Kelayakan model regresi dinilai dengan menggunakan Hosmer and Lemeshow's Goodness of Fit Test yang diukur dengan menggunakan nilai Chi-Square. Hosmer and Lemeshow's Goodness of Fit Test menguji hipotesis nol bahwa data empiris cocok atau sesuai dengan model karena tidak ada perbedaan antara model dengan data, sehingga model dikatakan fit (Ghozali, 2016:329).

d. Matriks Klasifikasi

Matriks klasifikasi menunjukkan kekuatan prediksi dari model regresi. Matriks klasifikasi digunakan untuk memprediksi variabel dependen pada penelitian ini, yaitu untuk memprediksikan kemungkinan penerimaan opini audit going concern pada perusahaan.

e. Estimasi Parameter dan Interpretasinya Estimasi Parameter dapat dilihat melalui koefisien regresi. Koefisien regresi dari tiap variabel-variabel yang diuji menunjukkan bentuk hubungan antara variabel yang satu dengan yang lainnya. Pengujian hipotesis untuk menguji signifikansi koefisien dari setiap variabel independen, dilakukan dengan cara membandingkan antara nilai probabilitas (sig). Jika Sig $\leq 0.05$, maka tolak Ho, namun jika Sig $\geq 0.05$, maka tidak tolak Ho.

\section{Hasil Dan Pembahasan}

\section{Uji Statistik Deskriptif}

Berdasarkan hasil uji statistik deskriptif pada tabel 1, 4 dari 5 variabel penelitian merupakan kategorial dengan nilai mean dan standar deviasi yang 
berbeda. 3 variabel yang memiliki nilai mean lebih kecil dibandingkan standar deviasinya yaitu variabel dependen going concern opinion (GCO), variabel independen debt default (DD) dan opinion shopping (OS). Nilai mean yang lebih kecil dibandingkan standar deviasinya menandakan kondisi yang masuk dalam kategori "l" pada tiap variabel penelitian tidak banyak muncul dari 180 sampel yang diteliti. Hal tersebut bertolak belakang dengan variabel financial distress (FD) yang memiliki nilai mean lebih besar dibandingkan standar deviasinya. Ini menandakan kondisi yang masuk dalam kategori " 1 " pada variabel financial distress merupakan kondisi yang paling banyak muncul dari 180 sampel yang diteliti. Variabel audit tenure (AT) yang menggunakan skala interval memiliki nilai minimum 1 dan maksimum 7. Nilai tersebut ditentukan berdasarkan perhitungan tahun perikatan antar auditor (KAP) dengan auditee dimulai tahun awal perikatannya, yang dalam penelitian ini dimulai tahun 2010 karena keterbatasan informasi. Nilai mean sebesar 3,15 menunjukkan bahwa rata-rata perikatan antara auditor (KAP) dengan auditee yang sama dalam penelitian ini adalah 3,15 tahun. Nilai standar deviasi yang lebih rendah dari mean, yaitu sebesar 2,004 menandakan bahwa data tidak homogen artinya persebarannya baik karena keragamannya rendah.

\section{Tabel 1}

Hasil Statistik Deskriptif

\begin{tabular}{ccccc}
\hline Variabel & Minimum & Maximum & Mean & Std.Deviasi \\
\hline GCO & 0 & 1 & 0,1833 & 0,38802 \\
\hline DD & 0 & 1 & 0,0778 & 0,26857 \\
\hline FD & 0 & 1 & 0,6278 & 0,48475 \\
\hline OS & 0 & 1 & 0,0611 & 0,24020 \\
\hline AT & 1 & 7 & 3,1500 & 2,00412 \\
\hline
\end{tabular}

Sumber: Hasil Pengolahan data dengan SPSS 20

\section{Uji Kesamaan Koefisien (Pooling)}

Berdasarkan hasil pengujian, nilai signifikansi untuk variabel debt default, financial distress, opinion shopping dan audit tenure lebih dari 5\% sehingga dapat diambil kesimpulan bahwa tidak terdapat perbedaan koefisien dan data dapat di-pool. Hasil pengujian dapat dilihat pada lampiran.

\section{Uji Regresi Logistik}

a. Menilai Keseluruhan Model Fit (Overall Model Fit)

Tabel 2

Iteration History

\begin{tabular}{cc}
\hline Iteration & -2Log Likelihood \\
\hline Step 0 & 171,508 \\
\hline
\end{tabular}

Step $1 \quad 121,937$

Sumber: Hasil pengolahan data dengan SPSS 20

Berdasarkan hasil uji pada tabel 2, terdapat penurunan nilai antara -2Log Likelihood awal (Step 0) dengan -2Log Likelihood akhir (Step 1) sebesar 49,571. Hal ini dapat diartikan bahwa penambahan variabel bebas ke dalam model dapat memperbaiki model fit serta menunjukkan model regresi yang lebih baik atau dengan kata lain model yang dihipotesakan fit dengan data.

b. Koefisien Determinasi (Nagelkerke's $R$ Square)

Tabel 3

Koefisien Determinasi

\begin{tabular}{ccc}
\hline $\begin{array}{c}-2 \text { Log } \\
\text { Likelihood }\end{array}$ & $\begin{array}{c}\text { Cox \& } \\
\text { Snell } \\
\text { Square }\end{array}$ & $\begin{array}{c}\text { Nagelkerke R } \\
\text { Square }\end{array}$ \\
\hline 121,937 & 0,241 & 0.392 \\
\hline
\end{tabular}

Sumber: Hasil pengolahan data dengan SPSS 20

Berdasarkan nilai koefisien determinasi yang ditunjukkan oleh nilai Nagelkerke's R Square pada tabel 3, dapat dilihat bahwa nilai Nagelkerke's R Square yang dihasilkan adalah 0,392 yang berarti variabel dependen dapat dijelaskan oleh variabel independen sebesar $39,2 \%$ sedangkan sisanya sebesar $60,8 \%$ dijelaskan oleh variabel-variabel lain di luar model penelitian.

c. Menilai Kelayakan Model Regresi

Tabel 4

\begin{tabular}{ccc} 
Uji Kelayakan Model Regresi \\
\hline Chi-square & df & Sig. \\
\hline 8.169 & 7 & 0,318 \\
\hline
\end{tabular}

Sumber: Hasil Pengolahan data dengan SPSS 20

Uji kelayakan model regresi dapat dilakukan dengan melihat nilai statistik Hosmer and Lemeshow pada tabel 4 yang memiliki nilai signifikansi sebesar 0,318 . Nilai signifikansi yang diperoleh ini lebih besar dari 0,05 yang berarti Ho tidak dapat ditolak. Hal ini menunjukkan bahwa tidak adanya perbedaan yang signifikan antara model dengan nilai yang diolah (observasi), sehingga model regresi ini dikatakan baik dan bisa dilanjutkan untuk analisis selanjutnya.

d. Matriks Klasifikasi

Matriks klasifikasi digunakan untuk memprediksi kemungkinan penerimaan opini audit going concern pada auditee yang dapat dianalisis dari classification tabel, yang disajikan pada tabel 5: 
Berdasarkan tabel diatas dapat diinterpretasikan bahwa kekuatan prediksi dari model regresi untuk memprediksi kemungkinan penerimaan opini audit going concern pada auditee adalah sebesar 48,5\%. Hal ini berarti bahwa dengan menunjukkan model regresi yang diajukan, terdapat 16 auditee $(48,5 \%)$ yang diprediksi akan menerima opini audit going concern dari total 33 auditee yang menerima opini audit going concern. Kekuatan prediksi dari model regresi untuk memprediksi kemungkinan perusahaan tidak menerima opini audit going concern adalah sebesar $95,9 \%$, yang berarti bahwa dengan model regresi yang diajukan, ada 141 auditee yang diprediksi akan menerima opini audit non going concern dari total 147 auditee yang menerima opini audit non going concern. Dengan demikian maka dapat disimpulkan bahwa ketepatan model dalam memprediksi variabel dependen sebesar $87,2 \%$.

\section{Tabel 5}

Tabel Klasifikasi

\begin{tabular}{|c|c|c|c|c|}
\hline \multirow{3}{*}{\multicolumn{2}{|c|}{ Observed }} & \multicolumn{3}{|r|}{ Predicted } \\
\hline & & \multicolumn{2}{|c|}{ GCO } & \multirow{2}{*}{ Percentage Correct } \\
\hline & & $\mathbf{0}$ & 1 & \\
\hline \multirow{2}{*}{ GCO } & $\mathbf{0}$ & 141 & 6 & 95,9 \\
\hline & $\mathbf{1}$ & 17 & 16 & 48,5 \\
\hline \multicolumn{4}{|c|}{ Overall Percentage } & 87,2 \\
\hline
\end{tabular}

e. Estimasi Parameter dan Interpretasinya

Tabel 6

Hasil Uji Koefisien Regresi Logistik

\begin{tabular}{ccccc}
\hline Keterangan & $\mathbf{B}$ & $\begin{array}{c}\text { Sig. } \\
\text { two } \\
\text { tailed })\end{array}$ & $\begin{array}{c}\text { Sig. (one } \\
\text { tailed })\end{array}$ & Keterangan \\
\hline DD & 3,127 & 0,000 & 0,000 & Tolak Ho \\
\hline FD & 1,296 & 0,038 & 0,019 & Tolak Ho \\
\hline OS & 3,087 & 0,000 & 0,000 & $\begin{array}{c}\text { Tidak } \\
\text { Tolak Ho }\end{array}$ \\
\hline AT & 0,297 & 0,021 & 0,0105 & $\begin{array}{c}\text { Tidak } \\
\text { Tolak Ho }\end{array}$ \\
\hline Constant & - & 0,000 & 0,000 & - \\
& 4,129 & & & \\
\hline
\end{tabular}

Sumber: Hasil pengolahan data dengan SPSS 20

Berdasarkan tabel 6, Hasil pengujian terhadap koefisien regresi menghasilkan model berikut ini:

$$
\operatorname{Ln} \frac{G C O}{1-G C O}=-4,129+3,127 \mathrm{DD}+1,29 \mathrm{FD}+
$$

Konstanta sebesar -4,129 dalam model berarti, jika variabel-variabel independen debt default, financial distress, opinion shopping, dan audit tenure bernilai nol, maka probabilitas penerimaan opini audit going concern akan turun sebesar 4,129. Persamaan di atas dapat menjelaskan bahwa koefisien regresi debt default, financial distress, opinion shopping dan audit tenure memiliki arah yang positif. Artinya setiap kenaikan status debt default, kondisi financial distress, perlakuan opinion shopping oleh manajemen dan makin lamanya tenure audit maka akan menaikan probabilitas penerimaan opini audit going concern sebesar nilai konstanta tiap variabel yaitu berturut-turut sebesar: 3,127, 1,296, 3,087 dan 0,297.

\section{Pembahasan}

\section{Pengaruh Debt Default Terhadap Penerimaan Opini Audit Going Concern}

Berdasarkan hasil uji regresi logistik yang ditunjukkan oleh tabel 6 untuk variabel debt default menunjukkan nilai signifikansi $0,000<0,05$ dengan nilai koefisien debt default sebesar 3,127. Nilai tersebut menunjukkan arah positif, maka hasil penelitian ini adalah tolak Ho yang berarti hasil uji regresi logistik berhasil mendukung Ha1 yang diajukan oleh penulis. Dari hasil penelitian terbukti bahwa variabel debt default berpengaruh signifikan positif terhadap penerimaan opini audit going concern. Hasil penelitian ini konsisten dengan hasil penelitian Chen dan Church (1992), juga beberapa penelitian yang telah dilakukan oleh (Ramadhany 2004; Praptitorini dan Januarti 2007; Januarti 2009; Astuti dan Darsono 2012; Nirmalasari 2014) yang mendapatkan bukti empiris bahwa debt default berpengaruh signifikan positif terhadap penerimaan opini audit going concen. Hal tersebut menunjukkan bahwa dengan adanya status debt default, maka semakin besar kemungkinan perusahan menerima opini audit going concern.

Dikatakan oleh Chen dan Church (1992) dalam (Ramadhany, 2004) beberapa kondisi seperti kesulitan dalam mentaati persetujuan utang serta faktafakta yang lalai atau pelanggaran akan memperjelas masalah going concern suatu perusahaan. Status debt default bisa diperoleh pada kondisi ekonomi yang dinamis seperti terjadinya fluktuasi nilai tukar mata uang rupiah yang dapat mengakibatkan jumlah utang perusahaan dalam mata uang asing meningkat dan dapat memicu terjadinya kerugian. Keadaan seperti itu dapat memengaruhi kemampuan perusahaan dalam memenuhi kewajiban pokok dan beban bunga serta 
perusahaan dapat mengalami rugi atas selisih kurs mata uang asing. Selain itu, kegagalan dalam membayar utang pada saat jatuh tempo juga dapat disebabkan oleh rugi operasi yang terus menerus terjadi sehingga berujung pada penurunan ekuitas. Saat itu terjadi maka aliran kas perusahaan akan banyak dialokasikan untuk membayar utang perusahaan, sehingga akan menggangu kelangsungan operasi perusahaan.

\section{Pengaruh Financial Distress Terhadap Penerimaan Opini Audit Going Concern}

Hasil uji regresi logistik yang ditunjukkan oleh tabel 6 untuk variabel financial distress menunjukkan nilai signifikansi $0,019<0,05$ dengan nilai koefisien sebesar 1,296. Nilai tersebut menunjukkan arah positif, maka hasil penelitian ini adalah tolak Ho yang berarti hasil uji regresi logistik berhasil mendukung Ha2 yang diajukan oleh penulis. Dari hasil penelitian terbukti bahwa variabel financial distress berpengaruh signifikan positif terhadap penerimaan opini audit going concern. Hasil penelitian ini konsisten dengan hasil penelitian yang telah dilakukan oleh (McKeown et al. 1991) yang menyatakan bahwa kondisi perusahaan yang buruk atau mengalami kesulitan keuangan akan meningkatkan kemungkinan perusahaan menerima opini audit going concern. Hasil penelitian ini juga mendukung hasil penelitian (Ramadhany 2004; Fanny dan Saputra 2005; Santosa dan Wedari 2007; Aziz 2008; Susanto 2009) yang telah menemukan bukti bahwa kondisi keuangan perusahaan berpengaruh signifikan terhadap penerimaan opini audit going concern. Hasil penelitian mereka membuktikan bahwa perusahaan dengan kondisi keuangan yang buruk (financial distress) membuat auditor cenderung memberikan opini audit going concern.

Pada penelitian ini, penggunaan Revised Altman Model untuk mengetahui nilai Z' Score perusahaan bukan untuk memprediksikan suatu perusahaan dalam kondisi bangkrut atau tidak, melainkan hanya untuk mengukur kondisi keuangan perusahaan saja. Jadi, berapapun nilai perhitungan dari Z' Score, tidak mengindikasikan perusahaan dalam keadaan bangkrut atau tidak bangkrut. Dengan demikian, diharapkan financial distress memiliki pengaruh yang positif dengan dikeluarkannya opini going concern, dimana jika kondisi keuangan perusahaan berada pada kondisi distress, maka kemungkinan dikeluarkannya opini going concern juga semakin besar.

\section{Pengaruh Opinion Shopping Terhadap Penerimaan Opini Audit Going Concern}

Hasil uji regresi logistik yang ditunjukkan oleh tabel 6 untuk variabel opinion shopping menunjukkan nilai signifikansi $0,000<0,05$ dengan nilai koefisien sebesar 3,087. Nilai koefisien yang positif bertolak belakang dengan Ha3 yang diajukan, maka hasil penelitian ini adalah tidak tolak Ho yang berarti bahwa variabel opinion shopping tidak berpengaruh terhadap penerimaan opini audit going concern. Hal ini berarti praktik opinion shopping yang dilakukan oleh perusahaan tidak memengaruhi penerimaan opini audit going concern.

Hasil penelitian ini tidak mendukung hasil penelitian (Lennox, 2000) yang menemukan adanya pengaruh negatif atas penerimaan opini going concern perusahaan-perusahaan di Inggris. Ketika perusahaan mengganti auditornya, maka akan menurunkan kemungkinan mendapatkan opini audit yang tidak diinginkan (opini audit going concern), daripada perusahaan yang tidak melakukan pergantian auditor. Namun, hasil penelitian ini sejalan dengan (Praptitorini dan Januarti, 2007), (Susanto, 2009), (Astuti dan Darsono, 2012) dan (Krissindiastuti dan Rasmini, 2016) yang mendapatkan bukti bahwa opinion shopping tidak berpengaruh terhadap penerimaan opini audit going concern. Menurut pendapat (Praptitorini dan Januarti, 2007), perusahaan di Indonesia cenderung menggunakan auditor independen yang sama apapun opini audit yang diberikan, karena perusahaan enggan untuk mengganti auditor independen.

Hasil penelitian ini menunjukkan bahwa praktik opinion shopping yang dilakukan di Indonesia tidak mengurangi independensi auditor saat mengaudit kliennya. Hal tersebut dapat terjadi karena auditor telah patuh akan regulasi yang telah ditetapkan oleh pemerintah. Jika perusahaan mengganti auditornya setelah mendapatkan opini audit going concern maka, belum tentu perusahaan sengaja mengganti auditornya untuk tujuan mendapatkan opini yang lebih baik dari sebelumnya. Bisa jadi hal tersebut dikarenakan pihak perusahaan tidak lagi merasa cocok dengan auditor yang lama ataupun terjadi masalah internal antara pihak perusahaan dengan auditor.

\section{Pengaruh Audit Tenure Terhadap Penerimaan Opini Audit Going Concern}

Hasil uji regresi logistik yang ditunjukkan oleh tabel 6 untuk variabel audit tenure menunjukkan nilai signifikansi $0,0105<0,05$ dengan nilai koefisien sebesar 0,297. Nilai koefisien yang postif bertolak belakang dengan Ha4 yang diajukan, maka hasil penelitian ini adalah tidak tolak Ho yang berarti bahwa variabel audit tenure tidak berpengaruh terhadap penerimaan opini audit going concern. Hasil penelitian ini tidak mendukung hasil penelitian (Januarti 2009), 
(Junaidi and Hartono 2010) dan (Krissindiastuti and Rasmini 2016) yang mendapat bukti bahwa variabel audit tenure berpengaruh negatif terhadap penerimaan opini audit going concern. Namun, hasil penelitian ini selaras dengan hasil penelitian (Nirmalasari 2014) yang menemukan bahwa variabel audit client tenure tidak berpengaruh signifikan terhadap penerimaan opini audit going concern.

Hasil penelitian ini menunjukkan bahwa, lamanya perikatan auditor (KAP) dengan auditee (perusahaan) tidak memengaruhi penerimaan opini audit going concern pada perusahaan. Dalam Peraturan Pemerintah Republik Indonesia Nomor 20 Tahun 2015 tentang Praktik Akuntan Publik telah diatur secara lengkap mengenai pemberian jasa audit oleh auditor. Lamanya waktu perikatan auditor dengan auditee tidak akan mengurangi independensi auditor dalam mengaudit laporan keuangan auditee. Dalam memberikan jasa auditnya kepada auditee, auditor akan mempertahankan reputasinya tanpa melihat kurun waktu perikatan dengan auditee Tidak terganggunya independensi membuat auditor dapat memberikan opini audit going concern jika memang ia menemukan keraguan atas kelangsungan hidup perusahaan yang sedang diaudit.

\section{Kesimpulan Dan Saran}

\section{Kesimpulan}

Berdasarkan hasil penelitian, maka dapat diambil kesimpulan bahwa debt default dan financial distress cukup bukti berpengaruh signifikan positif terhadap penerimaan opini audit going concern. Sedangkan tidak terdapat cukup bukti opinion shopping dan audit tenure berpengaruh negatif terhadap penerimaan opini audit going concern.

\section{Saran}

Berdasrkan hasil penelitian, peneliti menyarankan untuk peneliti selanjutnya agar dapat menambah rentang tahun penelitian, faktor-faktor lain yang sekiranya mempengaruhi penerimaan opini audit going concern, serta menggunakan proksi yang berbeda untuk tiap variabel penelitian. Sedangkan untuk perusahaan (pihak manajemen) dan investor agar memperhatikan aspek going concern seperti status default dan kondisi financial distress perusahaan yang dalam penelitian ini terbukti berpengaruh positif terhadap penerimaan opini audit going concern. Sehingga dapat mengambil keputusan terbaik yang menguntungkan.

\section{Daftar Pustaka}

Altman, Edward I (2000), "Predicting Financial Distress of Companies: Revisiting the ZScore and ZETA® Models", Handbook of Research Methods and Applications in Empirical Finance, July Vol. 53, p.428-56.

Astuti, Irtani Retno dan Darsono (2012), "Pengaruh Faktor Keuangan Dan Non Keuangan Terhadap Penerimaan Opini Audit Going Concern." Diponegoro Journal of Accounting, Vol. 1 No. 2, p.1-10.

Aziz, Very Abdul (2008), Tesis: Pengaruh Prediksi Kebangkrutan, Opini Audit Tahun Sebelumnya, Skala Auditor Dan Auditor Switching Terhadap Keputusan Pemberian opini Audit, Universitas Indonesia. Retrieved(www.lib.ui.ac.id).

Bursa Efek Indonesia, (2018) Laporan Keuangan dan Tahunan. Retrieved (http://www.idx.co.id/beranda/perusahaanter catat/laporankeuangandantahunan.aspx)

Fanny, Margaretta dan Sylvia Saputra (2005), "Opini Audit Going Concern: Kajian Berdasarkan Model Prediksi Kebangkrutan, Pertumbuhan Perusahaan, Dan Reputasi Kantor Akuntan Publik (Studi Pada Emiten Bursa Efek Jakarta)", SNA VIII Solo, 15 16 September 200, p.966-78.

Ghozali, Imam (2016), Aplikasi Analisis Multivariate dengan Program IBM SPSS 23, Badan Penerbit: Universitas Diponegoro.

Harvey, Hendricson dan Reza Espahbodi (1991), "Second Opinion, Opinion Shopping and Independence", The CPA Journal Online, Vol. 61 No. 3, p.26-29.

Institut Akuntan Publik Indonesia (2011), Standar Profesional Akuntan Publik (SPAP). Jakarta: Salemba Empat.

Januarti, Indira (2009), “Analisis Pengaruh Faktor Perusahaan, Kualitas Auditor, Kepemilikan Perusahaan Terhadap Penerimaan Opini Audit Going Concern ( Perusahaan Manufaktur Yang Terdaftar Di Bursa Efek Indonesia )", Jurnal Universitas Diponegoro, p.1-26.

Jensen, M. C. dan W. H. Meckling (1976), “Theory of the Firm: Managerial Behavior, Agency Costs and Ownership Structure", Journal of Financial Economics, Vol. 3 No. 4, p.305-60. 
Junaidi dan Jogiyanto Hartono (2010), "Faktor Non Keuangan Pada Opini Going Concern", SNA XIII Purwokerto, p.1-22.

Krissindiastuti, Monica dan Ni Ketut Rasmini (2016), "Faktor-Faktor Yang Mempengaruhi Opini Audit Going Concern", E-Jurnal Akuntansi Universitas Udayana, Vol. 14 No. 1, p.451-81.

Lennox, Clive Steven (2000), "Going-Concern Opinions in Failing Companies: Auditor Dependence and Opinion Shopping”, SSRN Electronic Journal, p.1-26.

McKeown, James C., Jane F. Mutchler, dan William S. Hopwood (1991), "Towards an Explanation of Auditor Failure to Modify the Audit Opinions of Bankrupt Companies", Auditing: A Journal of Practice \& Theory, Vol. 10, p.1-13.

Nirmalasari, Oktavia Tri (2014) "Analisis Pengaruh Debt Default, Auditor Client Tenure, Kualitas KAP, Disclosure Dan Ukuran Perusahaan Terhadap Penerimaan Opini Audit Going Concern (Studi Empiris Pada Perusahaan Manufaktur Yang Terdaftar Di Bursa Efek Indonesia Periode 2010-2012)", eprints.ums.ac.id.

Platt, Hd dan Mb Platt (2006), "Understanding Differences Between Financial Distress and Bankruptcy", Review of Applied Economics,
Vol. 2 No. 2, p.141-57.

Praptitorini, Mirna Dyah dan Indira Januarti (2007), "Analisis Pengaruh Kualitas Audit, Debt Default Dan Opinion Shopping Terhadap Penerimaan Opini Going Concern", Simposium Nasional Akuntansi X, Juli, p.1-25.

Ramadhany, Alexander (2004), “Analisa FaktorFaktor Yang Mempengaruhi Penerimaan Opini Going Concern Pada Perusahaan Manufaktur Yang Mengalami Financial Distress Di Bursa Efek Jakarta", JURNAL MAKSI, Vol. 4 No. 8, p.146-60.

Republik Indonesia. 2015. Peraturan Pemerintah No. 20 Tahun 2015 Tentang Praktik Akuntan Publik. Lembaran Negara RI Tahun 2015, No. 79. Sekretariat Negara. Jakarta

Santosa, Arga Fajar dan Linda Kusumaning Wedari (2007), “Analisis Faktor Faktor Yang Mempengaruhi Kecenderungan Penerimaan Opini Audit Going Concern", JAAI, Vol. 11 No. 2, p.141-58.

Susanto, Yulius Kurnia (2009), "Faktor-Faktor Yang Mempengaruhi Penerimaan Opini Audit Going Concern Pada Perusahaan Publik Sektor Manufaktur", Jurnal Bisnis Dan Akuntansi, Vol. 11 No. 3, p.155-73. 


\section{LAMPIRAN}

\section{Hasil Olah Data}

\section{Uji Statistik Deskriptif}

Descriptive Statistics

\begin{tabular}{|l|r|r|r|r|r|}
\hline & \multicolumn{1}{|c|}{$\mathrm{N}$} & Minimum & Maximum & \multicolumn{1}{c|}{ Mean } & Std. Deviation \\
\hline GCO & 180 & .00 & 1.00 & .1833 & .38802 \\
DD & 180 & .00 & 1.00 & .0778 & .26857 \\
FD & 180 & .00 & 1.00 & .6278 & .48475 \\
OS & 180 & .00 & 1.00 & .0611 & .24020 \\
AT & 180 & 1.00 & 7.00 & 3.1500 & 2.00412 \\
Valid N & 180 & & & & \\
(listwise) & & & & & \\
\hline
\end{tabular}

Uji Kesamaan Koefisien

Coefficients $^{\mathbf{a}}$

\begin{tabular}{|l|r|r|r|r|r|}
\hline \multirow{2}{*}{ Model } & \multicolumn{2}{|c|}{ Unstandardized Coefficients } & $\begin{array}{c}\text { Standardized } \\
\text { Coefficients }\end{array}$ & \multicolumn{1}{c|}{$\mathrm{t}$} & \\
\cline { 2 - 3 } & \multicolumn{1}{|c|}{$\mathrm{B}$} & Std. Error & \multicolumn{1}{c|}{ Beta } & & \\
\hline (Constant) & -.014 & .110 & & -.129 & .898 \\
DD & .369 & .185 & .256 & 1.993 & .048 \\
FD & .062 & .089 & .078 & .697 & .487 \\
OS & .587 & .180 & .363 & 3.260 & .001 \\
AT & .017 & .027 & .090 & .639 & .524 \\
D1 & -.051 & .153 & -.062 & -.332 & .740 \\
D2 & -.052 & .147 & -.063 & -.350 & .727 \\
DD_D1 & .209 & .251 & .080 & .835 & .405 \\
DD_D2 & .325 & .236 & .151 & 1.380 & .169 \\
FD_D1 & .102 & .127 & .108 & .808 & .420 \\
FD_D2 & .027 & .128 & .029 & .213 & .832 \\
OS_D1 & .279 & .300 & .076 & .930 & .354 \\
OS_D2 & -.316 & .253 & -.121 & -1.252 & .212 \\
AT_D1 & .017 & .035 & .085 & .498 & .619 \\
AT_D2 & .015 & .033 & .076 & .442 & .659 \\
\hline
\end{tabular}

a. Dependent Variable: GCO

\section{Overall Model Fit Test}

\section{Iteration History 0}

\begin{tabular}{|ll|r|r|}
\multicolumn{4}{|c|}{ Iteration History $\mathbf{a , b , c}$} \\
\hline \multirow{2}{*}{ Iteration } & -2 Log & Coefficients \\
\cline { 3 - 4 } & 1 & 172.967 & Constant \\
\hline Step 0 & 2 & 171.513 & -1.267 \\
& 3 & 171.508 & -1.479 \\
& 4 & 171.508 & -1.494 \\
& 4 & -1.494 \\
\hline
\end{tabular}


a. Constant is included in the model.

b. Initial -2 Log Likelihood: 171.508

c. Estimation terminated at iteration number 4 because parameter estimates changed by less than .001 .

\section{Iteration History 1}

Iteration History $\mathbf{y}^{\mathbf{a}, \mathbf{b}, \mathbf{c}, \mathbf{d}}$

\begin{tabular}{|c|c|c|c|c|c|c|c|}
\hline \multirow{2}{*}{\multicolumn{2}{|c|}{ Iteration }} & \multirow{2}{*}{$\begin{array}{c}-2 \log \\
\text { likelihood }\end{array}$} & \multicolumn{5}{|c|}{ Coefficients } \\
\hline & & & Constant & DD & FD & OS & AT \\
\hline \multirow{6}{*}{ Step 1} & 1 & 132.367 & -2.180 & 2.228 & .434 & 1.937 & .111 \\
\hline & 2 & 122.979 & -3.374 & 2.901 & .901 & 2.776 & .223 \\
\hline & 3 & 121.964 & -4.002 & 3.095 & 1.221 & 3.045 & 287 \\
\hline & 4 & 121.937 & -4.125 & 3.126 & 1.293 & 3.086 & 297 \\
\hline & 5 & 121.937 & -4.129 & 3.127 & 1.296 & 3.087 & 297 \\
\hline & 6 & 121.937 & -4.129 & 3.127 & 1.296 & 3.087 & .297 \\
\hline
\end{tabular}
a. Method: Enter
b. Constant is included in the model.
c. Initial -2 Log Likelihood: 171.508
d. Estimation terminated at iteration number 6 because parameter estimates changed by less than .001 .

\section{Uji Koefisien Determinasi (Nagelkerke's R Square)}

\section{Model Summary}

\begin{tabular}{|l|c|c|c|}
\hline Step & $\begin{array}{c}-2 \text { Log } \\
\text { likelihood }\end{array}$ & $\begin{array}{c}\text { Cox \& Snell R } \\
\text { Square }\end{array}$ & $\begin{array}{c}\text { Nagelkerke R } \\
\text { Square }\end{array}$ \\
\hline 1 & $121.937^{\mathrm{a}}$ & .241 & .392 \\
\hline
\end{tabular}

a. Estimation terminated at iteration number 6 because parameter estimates changed by less than .001 .

\section{Uji Kelayakan Model Regresi (Hosmer and Lemeshow Test)}

Hosmer and Lemeshow Test

\begin{tabular}{|l|r|r|r|}
\hline Step & Chi-square & df & Sig. \\
\hline 1 & 8.169 & & .318 \\
\hline
\end{tabular}

\section{Uji Matriks Klarifikasi}

\begin{tabular}{|c|c|c|c|c|c|}
\hline \multicolumn{6}{|c|}{ Classification Table $^{\mathbf{a}}$} \\
\hline & \multirow{3}{*}{\multicolumn{2}{|c|}{ Observed }} & \multicolumn{3}{|c|}{ Predicted } \\
\hline & & & \multicolumn{2}{|c|}{$\mathrm{GCO}$} & \multirow{2}{*}{$\begin{array}{c}\text { Percentage } \\
\text { Correct }\end{array}$} \\
\hline & & & .00 & 1.00 & \\
\hline \multirow{3}{*}{ Step 1} & & .00 & 141 & 6 & 95.9 \\
\hline & & 1.00 & 17 & 16 & 48.5 \\
\hline & Over & Percentage & & & 87.2 \\
\hline
\end{tabular}

a. The cut value is .500 


\section{Uji Estimasi Parameter}

Variables in the Equation

\begin{tabular}{|c|c|c|c|c|c|c|c|}
\hline & & B & S.E. & Wald & $\mathrm{df}$ & Sig. & $\operatorname{Exp}(B)$ \\
\hline \multirow{5}{*}{ Step $1^{\mathrm{a}}$} & DD & 3.127 & .745 & 17.617 & 1 & .000 & 22.795 \\
\hline & FD & 1.296 & .626 & 4.284 & 1 & .038 & 3.654 \\
\hline & OS & 3.087 & .864 & 12.760 & 1 & .000 & 21.904 \\
\hline & $\mathrm{AT}$ & .297 & .129 & 5.295 & 1 & .021 & 1.346 \\
\hline & Constant & -4.129 & .822 & 25.229 & 1 & .000 & .016 \\
\hline
\end{tabular}

a. Variable(s) entered on step 1: DD, FD, OS, AT. 